\title{
Uwarunkowania ksztaltowania priorytetów polityki zagranicznej Unii Europejskiej wobec państw Azji Centralnej po roku 2012 ${ }^{1}$
}

\section{Wprowadzenie}

Region Azji Centralnej ma powierzchnię ponad 4 mln $\mathrm{km}^{2}$ i zamieszkiwany jest przez około $69 \mathrm{mln}$ ludzi (dane z roku 2016). Stosunkowo niewielka liczba mieszkańców regionu nie jest obecnie kluczowym wskaźnikiem określającym znaczenie geopolityczne tej części świata. Choć przewiduje się znaczący wzrost populacji w tym regionie, do roku 2050 - 99,5 mln mieszkańców (United Nations, 2015), o jego znaczeniu decyduje przede wszystkim znaczący zasób surowców energetycznych, problematyczne sąsiedztwo istotnych graczy światowej sceny politycznej i tranzytowe położenie. Region sąsiaduje od wschodu z Chińską Republiką Ludową, od południa z Afganistanem i Iranem, a od zachodu i północy z Federacją Rosyjską. Sąsiedztwo wywierało i nadal wywiera ogromny wpływ na rozwój państw tego regionu. Państwa Azji Centralnej to swoiste pole realizacji politycznych i gospodarczych interesów dwóch, wzajemnie się uznających za partnerów, sąsiadów Chin i Federacji Rosyjskiej, a także pole rywalizacji z tymi sąsiadami Stanów Zjednoczonych. Co ważne, Azja Centralna jest także strategicznym obszarem tranzytowym. Przed pięć państw regionu przechodzą główne szlaki handlowe znaczące zarówno dla państw europejskich, jak i innych państw azjatyckich. Państwa Azji Centralnej zostały włączone do inicjatywy „Jeden pas i jedna droga” (ang. One Belt, One Road), w szczególności do tzw. pasa gospodarczego nowego szlaku jedwabnego (ang. New Silk Road Economic Belt). Analizując perspektywę zagrożeń dla bezpieczeństwa międzynarodowego należy podkreślić, iż region jest ważnym szlakiem tranzytu narkotyków między Afganistanem a Rosja. W konsekwencji czego, dla Europy obszar ten stanowi swoisty bufor mogący chronić przed zagrożeniem wynikającym z działalności grup przestępczych zajmujących się przemytem narkotyków i handlem ludźmi, ale także grup terrorystycznych. Państwa regionu stawiają opór zagrożeniu ekspansją ruchów islamskich ekstremistów. W tym regionie nasilają się wpływy ekstremistów religijnych, co znajduje odzwierciedlenie we wsparciu udzielanym IS/Daisz, Al-Kaidzie w Afganistanie i organizacji Hizb-at-Tahrir.

Pięć państw regionu Azji Centralnej, które uzyskały niepodległość po upadku Związku Radzieckiego w 1991 r., w znacznym stopniu różni się między sobą pod

${ }^{1}$ Artykuł został przygotowany w ramach projektu finansowanego przez Narodowe Centrum Nauki: „Unia Europejska wobec Azji Środkowej - uwarunkowania regionalne i międzynarodowe” 2014/15/B/HS5/01591. 
względem wielkości terytorium, populacji, zasobów naturalnych, wskaźników dobrobytu. Region charakteryzuje także zróżnicowanie etniczne i wyznaniowe. Państwa te łączy niski wskaźnik poziomu przestrzegania praw człowieka, demokracji i rządów prawa. W każdym z tych państw, zwłaszcza w Turkmenistanie i Uzbekistanie ${ }^{2}$, występują rażące uchybienia w przestrzeganiu powyżej wymienionych standardów. Na tym tle najlepiej sytuacja przedstawia się w Kirgistanie. Wszystkie państwa regionu charakteryzuje także bardzo wysoki, jeden z najwyższych na świecie, wskaźnik korupcji (Corruption..., 2015).

Cztery państwa regionu znajdują się wśród uznanych za średnio rozwinięte według wskaźnika HDI opisującego stopień rozwoju społeczno-ekonomicznego. W rankingu z roku 2015 państwa regionu zajęły następującą pozycję wśród 188 sklasyfikowanych: Turkmenistan - 109, Uzbekistan - 114, Kirgistan - 120, Tadżykistan - 129 (Transparency..., 2015). Kazachstan zajął najwyższe 56 miejsce, co odzwierciedla jak duża różnica w rozwoju społeczno-gospodarczym dzieli to państwo od pozostałych. Na płaszczyźnie gospodarczej Kazachstan jest regionalnym liderem. Dalsze miejsce zajmują Uzbekistan i Turkmenistan, które dysponują dużymi zasobami ropy i gazu. Ich eksport przekłada się na względnie wysoki poziom PKB na mieszkańca. Pozostałe państwa regionu Kirgistan i Tadżykistan są w dużo trudniejszej sytuacji ekonomicznej i nie odgrywają istotnej roli politycznej w regionie. Kirgistan ma bogate zasoby wodne, co jest istotne w regionie, gdzie dostęp do niej generuje liczne konflikty zwłaszcza z Uzbekistanem. Tadżykistan nadal odczuwa konsekwencje wyniszczeń spowodowanych wojną domową. $\mathrm{Z}$ uwagi na małe zasoby surowców, nieefektywny przemysł i nierozwinięte rolnictwo państwo to jest głównym beneficjentem zagranicznej pomocy gospodarczej.

W regionie Azji Centralnej występuje bardzo niski wskaźnik instytucjonalizacji współpracy. Państwa regionu więcej kwestii dzieli niż łączy. Region cechuje brak wzajemnego zaufania i wysokie napięcie związane z wykorzystywaniem zasobów naturalnych i dzieleniem się nimi. W najtrudniejszej, konfliktogennej sytuacji jest Uzbekistan graniczący z resztą państw regionu. Wzajemne stosunki pogarszają się przede wszystkim ze względu na spory dotyczące granic i co się z tym wiąże dostępu do zasobów. To uniemożliwia rozwój prawdziwej współpracy regionalnej. Jednocześnie państwa Azji Centralnej przynależą do różnych partnerstw zdominowanych przez wpływ Rosji lub Chin, takich jak Organizacja Układu o Bezpieczeństwie Zbiorowym, Szanghajska Organizacja Współpracy i Euroazjatycka Unia Gospodarcza. Zacieśnienie wzajemnych relacji w regionie, zwłaszcza w odniesieniu do transportu i energetyki, mogłoby sprzyjać rozwojowi społeczno-gospodarczemu. Integracja regionalna państw Azji Centralnej, integracja z rynkami międzynarodowymi i przyłączenie do międzynarodowych korytarzy w przyszłości stanowić mogłyby kluczowe elementy stabilizacji w wymiarze gospodarczym, ale także na rzecz budowania pokoju w regionie.

Azja Centralna ${ }^{3}$ jest miejscem coraz silniejszego oddziaływania aktorów międzynarodowych, w szczególności Federacji Rosyjskiej, Stanów Zjednoczonych, Chin

${ }^{2}$ Sytuacja w Uzbekistanie może ulec zmianie po wyborach zaplanowanych na 4 grudnia. Wybory ogłoszono po śmierci wieloletniego prezydenta Uzbekistanu Isłama Karimowa w dniu 2 września 2016 r.

${ }^{3}$ W tekście posłużono się terminem Azja Centralna w ujęciu politologicznym, ograniczając zasięg tego regionu w oparciu o kryteria antropogeograficzne do pięciu państw, dawnych republik ZSRR: Kirgistanu, Kazachstanu, Tadżykistanu, Turkmenistanu, Uzbekistanu. 
i państw Unii Europejskiej. Niestety, zaangażowanie UE i jej państw członkowskich w tym regionie jest znacznie mniejsze, niż można by tego oczekiwać wobec faktycznego rosnącego polityczno-gospodarczego znaczenia Azji Centralnej na świecie. Przyczyną tego zjawiska jest nie tyle brak spójnej unijnej strategii wobec Azji Centralnej, ale mała efektywność jej polityki zagranicznej, jak również skupienie uwagi na wzmocnieniu pozycji i roli w innych częściach świata.

Celem artykułu jest analiza priorytetów polityki zagranicznej Unii Europejskiej wobec Azji Centralnej po roku 2012. Priorytety zostały przedstawione w dwóch ujęciach: regionalnym i krajowym, które odzwierciedla politykę unijną skierowaną do poszczególnych państw regionu. Analizie podlegał pełen zakres dokumentów prawnych określających ramy wzajemnych relacji, jak i szersze spektrum obustronnych deklaracji politycznych. Kluczowymi elementami analizy stały się: uwarunkowania kreowania priorytetów politycznych, mechanizm instytucjonalny niezbędny do kształtowania decyzji politycznej, jak i realizacji określonych założeń współpracy. Końcowa część analizy prowadzi do wniosków pozwalających na ocenę możliwości realizacji założonych celów unijnej polityki w relacjach z państwami Azji Centralnej.

\section{Instytucjonalny wymiar relacji UE-Azja Centralna}

Od lat 90 proces ustanawiania ram prawnych i instytucjonalnych wspólnej polityki zagranicznej i bezpieczeństwa to jedno z największych wyzwań przywódców państw członkowskich. Idea przekształcenia Unii w silny podmiot stosunków międzynarodowych, oddziaływujący na swoje sąsiedztwo i angażujący się w rozwiązywanie najważniejszych problemów międzynarodowych, ewoluowała. Legitymizacja działań Unii przez państwa członkowskie wynikała z przeświadczenia, że siła oddziaływania grupowego, za pomocą wspólnych narzędzi i mechanizmów jest dużo większa, a proponowana wspólna polityka będzie o wiele bardziej efektywna, niż działania prowadzone przez każde państwo odrębnie od pozostałych. Uznano, że synergia środków reakcji pozwala na zagwarantowanie możliwości realizacji interesów gospodarczych, jak i odgrywania wskazanych ról politycznych, w tym, tej najbardziej podkreślanej, promotora określonych standardów przestrzegania demokracji, praworządności i praw podstawowych. Jednocześnie międzyrządowe, wewnętrzne spory toczone na kanwie ochrony partykularnych interesów państw uniemożliwiają skuteczne podejmowanie decyzji i uruchamianie pełnego wachlarza środków pozwalających na efektywne kształtowanie relacji z państwami trzecimi.

Przełomem na drodze do wzmocnienia aparatu instytucjonalnego Unii w obszarze kształtowania jej relacji zewnętrznych było wejście w życie w roku 2009 Traktatu lizbońskiego. Ten traktatowy impuls pozwolił na przekształcenie funkcji i roli Wysokiego Przedstawiciela Unii ds. zagranicznych i polityki bezpieczeństwa oraz powołanie podległej jemu Europejskiej Służby Działań Zewnętrznych. Unijna polityka zagraniczna jest realizowana przez Radę Europejską i Radę (głosowanie jednomyślne), ale w praktyce jej spiritus movens to Wysoki Przedstawiciel. Mianowane na tą funkcję Catherine Ashton, a później Federica Mogherini stanęły przed trudnym zadaniem stworzenia podwalin nowego systemu zarządzania mechanizmem unijnej polityki zagranicznej. 
Problem stanowiło zarówno zawiłe usytuowanie w aparacie instytucjonalnym poprzez łączenie funkcji wiceprzewodniczącego Komisji Europejskiej i przewodnictwa w Radzie do spraw zagranicznych, jak i główne zadanie koordynacji wszystkich aspektów działań zewnętrznych, ściśle przestrzegając wytycznych ministrów spraw zagranicznych państw członkowskich. Zadanie to wydawało się arcytrudne w obliczu narastającego kryzysu solidarności. Państwa członkowskie zaaferowane rozwiązywaniem coraz liczniejszych problemów w obszarze spraw gospodarczych, musiały jednoczyć siły w obliczu wyzwań, które wynikały z narastających napięć i niestabilności sytuacji w bliższym i dalszym sąsiedztwie.

Wart odnotowania jest wewnętrzny dysonans między pracami Komisji i Europejskiej Służby Działań Zewnętrznych. W wielu kwestiach, zwłaszcza w obszarze realizacji założeń gospodarczych wymiaru zewnętrznego polityk unijnych Komisja Europejska ma szeroki zakres kompetencji i uzupełnia działania ESDZ. Wypracowanie modelu koordynacji KE i ESDZ wymagało kilku lat trudnych negocjacji międzyinstytucjonalnych. $\mathrm{Na}$ szczególną uwagę zasługuje współpraca Dyrekcji Generalnej ds. Rozwoju i Współpracy EuropeAid w Komisji oraz ESDZ (wcześniej DG Komisji RELEX), które są odpowiedzialne za formułowanie polityki współpracy na rzecz rozwoju UE, przede wszystkim za wieloletnie planowanie instrumentów pomocy zewnętrznej.

Unijna dyplomacja rodziła się w okresie, w którym narastające problemy wewnętrzne powodowały coraz większą niechęć w społeczeństwach europejskich do użycia wspólnych mechanizmów. W roku 2014 w wyborach do Parlamentu Europejskiego wybrano największą od początku powstania EWG/UE liczbę przedstawicieli partii eurosceptycznych, niechętnych dalszemu rozwojowi procesu integracji europejskiej. Elementy wewnętrznych przekształceń Unii, a zwłaszcza jej zdolność do przezwyciężania kryzysów wewnętrznych, stanowią główną determinantę stanowionych relacji zewnętrznych.

W kontekście relacji UE-Azja Centralna zmiany wprowadzone w roku 2009 przyniosły nową instytucjonalną formułę opartą na unijnym korpusie dyplomacji pracowników ESDZ zatrudnionych w Brukseli, jak i pracowników tej służby oddelegowanych do pracy w delegaturach w państwach regionu. W Europejskiej Służbie Działań Zewnętrznych powołano specjalną komórkę organizacyjną zajmującą się sprawami relacji z Azją Centralną (EURCA.EAST.4). Komórka ta przejęła znaczącą część działań będących wcześniej w zakresie kompetencji utworzonej jednostki w Komisji Europejskiej. Oprócz brukselskiego, kilkuosobowego zespołu odpowiedzialnymi za relacje z Azją Centralną są pracownicy unijnej dyplomacji oddelegowani do pracy w państwach regionu. W regionie działają cztery unijne delegatury ESDZ w: Kazachstanie, Kirgistanie, Tadżykistanie oraz Uzbekistanie. W Turkmenistanie otwarto jedynie Biuro Łącznikowe. Unijne delegacje kontynuują prace wcześniej funkcjonujących w tych państwach przedstawicielstw Komisji Europejskiej.

Symbolicznym podkreśleniem znaczenia regionu było powołanie w 2005 roku Specjalnego Przedstawiciela Unii Europejskiej do spraw Azji Centralnej, którym został Słowak Ján Kubiš (28.06.2005-5.06.2006). Wspiera on działania Wysokiego Przedstawiciela w państwach i regionach, gdzie występuje szczególna sytuacja, bądź konkretny problem wymagający zaangażowania Unii. W przypadku Azji Centralnej ustanowienie Specjalnego Przedstawiciela bezpośrednio nie było powiązane z sytuacją wewnętrzną regionu, ale jego sąsiedztwa i wpływu Azji Centralnej na to sąsiedztwo. 
Dotyczyło to zagrożeń dla bezpieczeństwa wynikających z sytuacji w Afganistanie. W kolejnych latach funkcję tą pełnili Francuz Pierre Morel (5.10.2006-30.06.2012) oraz Niemka Patricia Flor (1.06.2012-30.06.2014). 15 kwietnia 2015 roku funkcję tą przejął Słowak Peter Burian. Stał się on jednym z dziewięciu wysłanników Wysokiego Przedstawiciela do regionów uznanych za wymagające szczególnego zainteresowania. Jego powołanie było potwierdzeniem kontynuacji współpracy UE z Azją Centralną i chęci zapewnienia obecności i zaangażowania w kluczowych kwestiach będących przedmiotem wspólnego zainteresowania. Przy jego powołaniu wymienione zostały następujące obszary współpracy UE-Azja Centralna, które miał monitorować: praworządność i prawa człowieka, bezpieczeństwo, energia, dostawy wody, edukacja.

Aktywność w zakresie kształtowania relacji UE-Azja Centralna przejawia także Parlament Europejski, w którego ramach wyodrębniona została „Delegacja do Komisji Współpracy Parlamentarnej UE-Kazachstan, UE-Kirgistan, UE-Uzbekistan i UE-Tadżykistan oraz do spraw Stosunków z Turkmenistanem i Mongolią"4. W kadencji 2014-2018 zainteresowanie udziałem w pracach tej Komisji zadeklarowało 18 posłów. Jest ona jedną z mniejszych komisji, zdominowaną przez przedstawicieli mniej licznych frakcji politycznych. To może być uznane za wyraz małego zainteresowania posłów tematyką relacji z tym regionem. Połowę składu Komisji stanowią przedstawiciele państw Europy Środkowo-Wschodniej (Łotwy, Litwy, Estonii, Polski, Wegier, Bułgarii, Czech). Stanowi to tradycyjny geograficzny wyznacznik zainteresowania posłów kierunkiem polityk dalszego i bliższego sąsiedztwa. W komisjach zajmujących się polityką wschodnią, współpracą z Federacją Rosyjską, relacjami z Azją Centralną znaczącą grupę stanowią posłowie państw Europy Środkowo-Wschodniej.

Od roku 2004 do 2016 Parlament Europejski przyjął 20 rezolucji dotyczących spraw państw Azji Centralnej, w tym 15 poświęconych kwestiom przestrzegania praw człowieka i podstawowych wolności. Nie jest to zbyt duża liczba w porównaniu do innych regionów. Symbolicznym potwierdzeniem małego zainteresowania regionem Azji Centralnej wśród europosłów była obecność tylko 12 mówców podczas parlamentarnej debaty nad strategią Unii dotyczącą tego regionu ${ }^{5}$. Debatę zaplanowano w późnych godzinach wieczornych 13 kwietnia 2016 roku. Całość debaty trwała 31,5 minuty.

Opisując ramy instytucjonalne relacji UE - poszczególne państwa Azji Centralnej warto także wskazać na wspólne organy ustanowione w oparciu o umowy o partnerstwie i współpracy z poszczególnymi państwami regionu. Wspólne instytucje utworzono z czterema państwami sygnatariuszami umów. Wyjątek stanowi Turkmenistan z uwagi na przedłużający się proces ratyfikacji umowy. Na rzecz realizacji i monitorowania przyjętych umów powołano: Rady Współpracy, Komitety Współpracy, Parlamentarne Komisje Współpracy. Rada Współpracy składa się z członków rządu

${ }^{4}$ Delegacja kontynuuje prace powstałej w roku 1994 Delegacji do spraw Wspólnoty Państw Niepodległych. Por. Delegation to the EU-Kazakhstan, EU-Kyrgyzstan, EU-Tajikistan and EU-Uzbekistan Parliamentary Cooperation Committees, and for relations with Turkmenistan and Mongolia (DCAS), Brief History of the Delegation, https://polcms.secure.europarl.europa.eu/cmsdata/upload/2a5eec0fa111-45ad-8026-0bdb50acd620/att_20141113ATT93317-1436386817946666497.pdf.

${ }_{5}$ Podczas spotkania przyjęto rezolucję dotyczącą Strategii. Por. European Parliament resolution of 13 April 2016 on implementation and review of the EU-Central Asia Strategy (2015/2220(INI)) P8_T-PROV(2016)0 121. 
oraz z członków Rady Unii Europejskiej i Komisji Europejskiej. Rada zbiera się na szczeblu ministerialnym raz w roku. Komitet Współpracy składa się z przedstawicieli członków Rady Unii Europejskiej i Komisji Europejskiej oraz przedstawicieli rządów poszczególnych państw azjatyckich, zazwyczaj na szczeblu wyższych urzędników służby cywilnej. Komitet Współpracy obejmować może podkomisje na poziomie ekspertów np.: w obszarze „Sprawiedliwość, wolność i bezpieczeństwo”; w sprawie handlu, w sprawie inwestycji, energii i transportu. Powołano także Parlamentarne Komisje Współpracy, które służą jako forum dialogu politycznego. Składają się one z członków parlamentów narodowych państw Azji Centralnej i Parlamentu Europejskiego. Wspólne spotkania przedstawicieli PE z ich partnerami z Kazachstanu, Kirgistanu i Uzbekistanu odbywają się regularnie od 2000 roku (z Tadżykistanem od 2010). W kolejnych latach widać znaczący wzrost liczby spotkań UE z przedstawicielami państw Azji Centralnej.

\section{Przegląd dokumentów prawnych ksztaltujących relacje UE-Azja Centralna}

Za początek relacji UE-Azja Centralna uznać należy moment rozpadu Związku Radzieckiego. 16 grudnia 1991 roku odbyło się spotkanie ministrów spraw zagranicznych EWG, aby zdecydować o stanowisku wobec rozwiązania ZSRR. Jedną z ważnych decyzji podjętych podczas tego spotkania było ustanowienie programu TACIS skierowanego do Wspólnoty Państw Niepodległych i Mongolii. Choć delegacje instytucji europejskich przyjeżdżały do republik radzieckich Azji Centralnej jeszcze przed formalnym uzyskaniem niepodległości przez państwa regionu, formalne rozmowy dotyczące nawiązania obustronnych relacji miały miejsce dopiero w latach 1992-1993. Pierwszym państwem, które w lutym 1993 roku nawiązało oficjalnie relacje z UE był Kazachstan. Pierwsze kazachskie przedstawicielstwo w Brukseli otworzono w grudniu 1993 roku. Ramy wzajemnych relacji UE z poszczególnymi państwami Azji Centralnej kształtować miały umowy o partnerstwie i współpracy z UE. Pierwsze rozmowy na temat zawarcia tych umów podjęto w roku 1993. Umowy z Kazachstanem, Kirgistanem i Uzbekistanem zawarte zostały w roku 1995, a weszły w życie w roku 1999. Umowa z Tadżykistanem weszła w życie dopiero w roku 2010. Umowa z Turkmenistanem zawarta $\mathrm{w}$ roku 1998 nie została jeszcze ratyfikowana przez stronę unijną. Umowa została zablokowana $\mathrm{z}$ uwagi na sytuację dotyczącą przestrzegania praw człowieka ${ }^{6}$. Obowiązującym aktem określającym relacje z tym państwem jest przejściowa umowa handlowa z roku 1998, która weszła w życie 1 sierpnia 2010 roku (ang. Interim Trade Agreement). Istniejące umowy o partnerstwie i współpracy to niepreferencyjne umowy handlowe, zgodnie z którymi strony przyznają sobie wzajemnie klauzulę najwyższego uprzywilejowania w odniesieniu do taryf. Umowa przewiduje również stopniową harmonizację prawodawstwa i praktyk krajowych z normami UE związanych $\mathrm{z}$ handlem, w tym przepisów technicznych i wymogów sanitarnych i fitosanitarnych, ochrony praw własności intelektualnej i zagadnień celnych.

${ }^{6}$ Umowa o partnerstwie i współpracy z Turkmenistanem z 1998 r. może zostać zatwierdzona przez Parlament Europejski na przełomie 2016/2017 roku. Warunkiem koniecznym ma być postęp w dziedzinie przestrzegania praw człowieka w tym państwie. 
W praktyce, w pierwszych latach podjęta współpraca między państwami regionu a UE dotyczyła głównie handlu i inwestycji. Stopniowo, po roku 2002, z uwagi na zmieniającą się sytuację wewnętrzną w państwach regionu i konkurencję Chin i Federacji Rosyjskiej, poszerzano obszary współpracy o istotne dla UE kwestię energetyczne. Ważnym deklarowanym przez stronę unijną obszarem współpracy był także dialog polityczny dotyczący praw podstawowych. W tym zakresie unijne postulaty w dużej mierze nie były możliwe do zaakceptowania, ale często także były niezrozumiałe dla władz państw Azji Centralnej. W pierwszych latach współpracy dominowały relacje bilateralne UE - poszczególne państwa regionu. Rzadkością były spotkania w układzie regionalnym. Dla Unii rolę lidera regionalnego pełniła delegacja kazachska z uwagi na potencjał i znaczenie gospodarcze tego państwa. Zmieniające się uwarunkowania gospodarcze wymusiły decyzje o podjęciu negocjacji w sprawie nowych ram umów o partnerstwie i współpracy z Kazachstanem. Proces ich przygotowania i ratyfikacji nie był łatwy. Strony miały diametralnie różne spojrzenia na wzajemne relacje. Początek negocjacji z Kazachstanem miał miejsce 27 czerwca 2011 roku w Brukseli. Po 8 rundach negocjacyjnych 9 października 2014 r. uroczyście, w obecności przewodniczącego Komisji Europejskiej J. M. Barosso i Prezydenta Kazachstanu Nazarbayewa podpisano Protokół o zamknięciu negocjacji. 20 stycznia 2015 roku Umowa o Partnerstwie i Współpracy między UE a Kazachstanem została parafowana. W grudniu tego samego roku podpisano ją w Astanie. Oczekuje ona na ratyfikację, ale stosuje się jąjuż tymczasowo od 1 maja $2016 \mathrm{r}$.

Współpraca Unii z państwami Azji Centralnej odbywa się na dwóch płaszczyznach: regionalnej i krajowej. W ujęciu regionalnym powstają wieloletnie strategie współpracy, których szczegóły zawiera dokument o nazwie Regionalny dokument strategiczny wsparcia dla Azji Środkowej 2007-2013 (European Commission, 2007). W oparciu o ten dokument wydatkowane są środki unijne pochodzące z funduszy celowych UE. W okresie 2007-2013 projekty finansowane w ramach tego dokumentu dotyczyły przede wszystkim takich obszarów jak: edukacja, praworządność, woda i ochrona środowiska, zarządzanie granicami, walka z przestępczością narkotykową. W kolejnym okresie programowania zakres obszarów wsparcia nie uległ znaczącym modyfikacjom. Ponadto programy współpracy są przygotowywane na płaszczyźnie relacji bilateralnych. Przyjmują one postać wieloletnich narodowych programów indykatywnych (ang. National Indicative Programme). Nowo przygotowane ramy obejmują okres 2014-2020. Uwzględniają one sytuację i szczególne potrzeby każdego państwa w danym okresie, tzw. perspektywie obowiązywania finansowych instrumentów wparcia.

Należy wskazać, że Unia w relacjach z państwami Azji Centralnej przyjęła zasadę „więcej za więcej”. Założenie to oznacza, że zwiększenie zaangażowania unijnego, także w jego wymiarze finansowym, jest uzależnione od postępów w odniesieniu do reform politycznych i społeczno-gospodarczych.

W uzupełnieniu do Umów o partnerstwie i współpracy, podpisane zostały także inne umowy w obszarach wspólnego zainteresowania. Istnieją trzy umowy podpisane między Kazachstanem i Europejską Wspólnotą Energii Atomowej dotyczące bezpieczeństwa jądrowego: Umowa o współpracy w dziedzinie bezpieczeństwa jądrowego z czerwca 1999 r.; weszła w życie w czerwcu 2003 r.; Umowa o współpracy w dziedzi- 
nie kontroli rozprzestrzeniania się broni nuklearnej podpisana w listopadzie $2002 \mathrm{r}$.; weszła w życie w kwietniu 2004 r.; Umowa o współpracy w dziedzinie pokojowego użycia energii nuklearnej podpisana w grudniu 2006 r.; weszła w życie we wrześniu 2008 r. Do innych, ważnych umów należy zaliczyć memorandum dotyczące transportu podpisane z Kazachstanem oraz memorandum dotyczące współpracy energetycznej podpisane z Kazachstanem i Turkmenistanem w roku 2008, a z Uzbekistanem w roku 2011.

Przełomowym dokumentem kształtującym relacje Unia Europejska-Azja Centralna była unijna strategia, która została przyjęta w roku 2007. Przyjęcie strategii oznaczało wyraz uznania rosnącego znaczenia tego regionu dla bezpieczeństwa państw europejskich (Melvin, 2012). Przyjęcie strategii należy analizować w kontekście zaangażowania państw UE w sąsiedztwie tego regionu, czyli w Afganistanie, a także rozszerzenia europejskiej polityki sąsiedztwa na region Morza Kaspijskiego. Strategia to także wyraz konieczności wzmocnienia realizacji interesów UE w obszarze jej bezpieczeństwa energetycznego. Nie należy także zapominać o stałym elemencie polityki zagranicznej UE, jakim jest promowanie wsparcia dla reform i modernizacji społeczeństw w kierunku przekształceń demokratycznych.

Strategia Unii wobec Azji Centralnej określiła podstawowe wytyczne dla unijnych działań w tym regionie. Jej podstawy odnoszą się w dużej mierze do wcześniejszych zobowiązań zawartych w umowach oraz doświadczeń kilku programów i inicjatyw oferujących wsparcie finansowe. Rada określiła w niej długoterminowe obszary priorytetowe: poszanowanie praw człowieka i praworządności, dobre rządy i demokratyzacja, edukacja, rozwój gospodarczy, handel i inwestycje, energia i transport, zrównoważenie środowiskowe i gospodarka wodna, radzenie sobie ze wspólnymi zagrożeniami dla bezpieczeństwa i wyzwania w tej dziedzinie oraz dialog międzykulturowy. Proponowany w strategii dialog polityczny miał odbywać się przede wszystkim na poziomie regularnych spotkań ministerialnych. Zapisanym w tym dokumencie celem współpracy jest „osiagnięcie stabilności i dobrobytu przy jednoczesnym promowaniu otwartego społeczeństwa, praworządności, demokratyzacji oraz ściślejszej współpracy w obszarze bezpieczeństwa energetycznego i dywersyfikacji źródeł energii” (Council, 2007).

Dwukrotnie, w 2012 i 2015 roku, dokonano przeglądu tej strategii. Do roku 2016 już czterokrotnie przedstawiono sprawozdania z postępów jej realizacji. We wszystkich wymienionych dokumentach podkreślono, że zacieśnienie stosunków dwu- i wielostronnych ze wszystkimi państwami Azji Centralnej leży w istotnym interesie strategicznym, politycznym i gospodarczym UE. Jednocześnie wskazano, że realizacja Strategii jest możliwa tylko przy zaangażowaniu drugiej strony (Boonstra, Tsertsvadze, 2016, s. 13) Zwracano uwagę na postęp w realizacji założeń strategii jednakże tylko w kilku obszarach. Widoczna jest znacząca koncentracja na współpracy energetycznej i zapewnieniu bezpieczeństwa dostaw. Promowane standardy demokracji i poszanowania praw człowieka pozostają w sferze deklaracji (Boonstra, 2015). Analizując założenia ostatniego przeglądu należy wskazać, iż ocena realizacji strategii jest coraz bardziej krytyczna. Wskazuje się w nim, iż tylko w ograniczonym stopniu doszło do rozbudowy powiązań gospodarczych między UE a państwami Azji Centralnej objętymi strategią. Ponadto dążenie do promowania współpracy i integracji regionalnej państw Azji Środkowej w drodze wymiany doświadczeń i norm z UE „znajduje 
się w fazie stagnacji” (Sprawozdanie..., 2015.). To co zostało wskazane to fakt złego dopasowania do interesów, wymagań i warunków ramowych państw partnerskich, z uwzględnieniem różnic między państwami tego regionu i szczególnej sytuacji każdego z nich. Wskazuje się, że w przyszłości ramy wsparcia powinny być skrojone „na miarę”, co odzwierciedlone być powinno w krajowych planach działania. Przyjęte plany powinny być bardziej elastyczne by dostosować je do rzeczywistych warunków w tym regionie. Za właściwe zatem uznano przyjęcie podejścia zróżnicowanego do każdego z państw, nadal opartego na warunkowości, a tym samym na tworzeniu pakietu zachęt, aby osiagnąć lepsze wyniki zarówno w wymiarze dwustronnym, jak i regionalnym. W tym zakresie wskazuje się głównie programy regionalne, te finansujące ważne dla Unii obszary dotyczące zarządzania granicami, zwalczania narkotyków i nielegalnego handlu, a także energii.

Realizacja strategii jest możliwa przy pomocy pełnego wachlarza instrumentów finansowych współpracy na rzecz rozwoju. Ich mechanizm wdrażania określa szereg aktów prawnych. Państwa Azji Centralnej korzystają z Instrumentu Współpracy na rzecz Rozwoju, a także Instrumentu na rzecz Stabilności. Kazachstan, Kirgistan, Tadżykistan korzystają także z Europejskiego Instrumentu na rzecz Wspierania Demokracji i Praw Człowieka. Uzbekistan i Turkmenistan zostały wyłączone ze wsparcia. Wynika to z unijnej oceny stanu rozwoju społeczeństwa obywatelskiego.

W okresie 2007-2013 suma środków wdrożonych z Instrumentu Współpracy na rzecz Rozwoju wyniosła około 750 mln euro (Tsertsvadze, Boonstra, 2016). W kolejnej perspektywie finansowej 2014-2020 wysokość środków podniesiono do $1028 \mathrm{mln}$ euro. Kwota ta dotyczy zarówno programów dwustronnych (środków przeznaczonych dla jednego państwa ${ }^{7}$ ), jak i regionalnych. Na programy regionalne przeznaczono około jednej trzeciej całej kwoty finansowania współpracy. Główne obszary wsparcia programów to: edukacja, rozwój społeczno-gospodarczy, zrównoważony rozwój zasobów naturalnych, bezpieczeństwo w regionie. Pomimo dużego wzrostu nakładów, nadal przewidziana kwota jest niezwykle niska w odniesieniu do potrzeb, a przede wszystkim założeń współpracy. Co ważne, ta stosunkowo mała kwota jest alokowana w wielu obszarach, zatem kwoty na poszczególne projekty nie są wysokie, przy stosunkowo dużej liczbie projektów. To rodzi ogromny problem z ich obsługą. W 2011 roku liczba pracowników zajmujących się pomocą rozwojową w trzech unijnych delegaturach wynosiła 74 (Europejski Trybunał, 2013). Do tego w wielu przypadkach zawyżone oczekiwania prowadzą do nierealnych założeń związanych z alokacją tych środków (Tservadze, Boonstra, 2015). Problemem dla administracji państw azjatyckich są zbiurokratyzowane i skomplikowane procedury wydatkowania unijnych funduszy. Zwraca się także uwagę na to, że pomoc często przechodzi przez pośredniczące agencje państw członkowskich lub organizacji międzynarodowych działających w regionie i wyposażonych w wykwalifikowaną kadrę ekspercką, co skutkuje tym, że środki kojarzone są jako niemiecka lub francuska pomoc, a nie unijne wsparcie.

Z danych systemu RELEX (CRIS) Komisji Europejskiej wynika, że w latach 19912013 UE przeznaczyła na pomoc rozwojową i humanitarną dla państw Azji Centralnej ponad 2,1 mld euro, z czego znaczącą część 750 mln euro w okresie 2007-2013.

${ }^{7}$ W nowym okresie programowania Kazachstan będzie korzystał wyłącznie z programów regionalnych. 
Głównymi beneficjentami wparcia były Kirgistan i Tadżykistan, w których alokowano połowę sumy wsparcia. Unia nie jest $\mathrm{w}$ tym regionie głównym donatorem pomocy rozwojowej. Pozycję lidera w rankingu głównych donatorów zajmuje gdy do środków UE dodamy oficjalną pomoc rozwojową jej poszczególnych państw członkowskich. Średniorocznie pomoc unijna po roku 2010 wynosiła około $90 \mathrm{mln}$ \$, a pomoc Stanów Zjednoczonych około $170 \mathrm{mln}$, Turcji $160 \mathrm{mln}$ \$, Niemiec $100 \mathrm{mln}$ \$ (dane OECD).

Analizując dotychczasowe priorytety rozdysponowanych środków należy stwierdzić, iż jednym z obszarów, który w najbliższych latach powinien być uznany za priorytetowy w zakresie wsparcia jest zarządzanie gospodarką wodną. To w tym obszarze eksperci państw członkowskich mogą być uznani za najbardziej pomocnych w rozwiązaniu kluczowych dla przyszłości gospodarczej problemów państw Azji Centralnej. UE może wpisać się w ramy tzw. „dyplomacji wodnej”, aby przyczynić się do poprawy transgranicznej gospodarki wodnej oraz zapewnić mediacje na rzecz rozstrzygania sporów obejmujących na przykład problem zapory roguńskiej.

\section{Obszary współpracy Unia Europejska - państwa Azji Centralnej w okresie 2012-2016}

Oceniając stan współpracy UE-państwa Azji Centralnej po roku 2012 można potwierdzić, iż nadal wszystkie państwa regionu mniej lub bardziej umiejętnie balansują między Federacją Rosyjską i Chinami, a relacje z państwami Europy Zachodniej coraz bardziej marginalizują, Większość państw Azji Centralnej, z wyjątkiem Kazachstanu i Turkmenistanu, stopniowo ogranicza dotychczasowe ramy współpracy do niezbędnego minimum.

\section{Wspótpraca gospodarcza}

Należy wskazać, iż kluczowym dla UE, z punktu widzenia interesów gospodarczych, państwem regionu jest Kazachstan. Osiaga on najwyższe wskaźniki wzrostu gospodarczego. W 2015 r. Kazachstan osiagnął ostatni etap ubiegania się o członkostwo w WTO $^{8}$. Kazachstan jest także pierwszym partnerem, z którym UE wynegocjowała i podpisała poszerzoną umowę o partnerstwie i współpracy. W perspektywie kolejnej dekady rozwoju współpracy z regionem Azji Centralnej należy uznać za mające zasadnicze znaczenie wdrażanie osiagniętego porozumienia.

Unia Europejska stopniowo stała się pierwszym partnerem handlowym Kazachstanu, z ponad 30\% udziałem w ogólnej wartości handlu zagranicznego w roku 2013 i 2014. W 2014 roku eksport z UE do Kazachstanu był wart 6,7 mld euro, a import z Kazachstanu wyniósł 23,9 mld euro. Obroty powyżej 30 mld euro usytuowały Kazachstan na 26 pozycji wśród partnerów handlowych Unii Europejskiej (15 miejsce wśród importerów). Istotnym elementem obrotu handlowego, wpływającym na ogólny bilans, były surowce energetyczne. Unijny import jest zdominowany przez

\footnotetext{
${ }^{8}$ Kirgistan jest członkiem WTO od roku 1998, a Tadżykistan od roku 2013.
} 
produkty energetyczne (ponad 90\% w 2014 roku). Główny eksport z UE stanowią maszyny, chemikalia i pojazdy. Wiele $\mathrm{z}$ tych produktów to zaopatrzenie dla europejskich firm naftowych i gazowych. Unia Europejska jest także największym inwestorem w Kazachstanie. W okresie 2000-2014, inwestycje UE brutto wyniosły około 106 mld USD. Od dekady, średniorocznie, wartość unijnych inwestycji stanowi ponad $40 \%$ ogółu zainwestowanych w tym państwie środków. Tu także na pierwszym miejscu są inwestycje w sektorze energetycznym. Obroty handlowe z Kazachstanem to ponad 32\% łącznych obrotów wszystkich państw regionu. Drugie miejsce zajmuje Turkmenistan (ok. 16\%), a trzecie, ustępując nieznacznie, Uzbekistan (ok. 15\%). To najludniejsze państwo regionu, choć ustępuje Kazachstanowi w ilości zasobów energetycznych, dysponuje największymi zasobami złota i srebra w regionie. Analizując obroty handlowe, należy zwrócić uwagę na bardzo dużą dysproporcję między udziałem w wolumenie importu i eksportu (Olędzki, 2014, s. 46).

W relacjach handlowych z Kazachstanem, jak i pozostałymi państwami regionu Unia ma konkurentów, przede wszystkim Chiny i Federację Rosyjską. Chiny przekształcają się z zewnętrznego partnera handlowego w regionalnego mediatora $\mathrm{w}$ zakresie zarządzania gospodarczego, co dla państw regionu stanowi swoiste uzależnienie w zakresie zapewniania dóbr publicznych. Chińska inicjatywa „One Belt, One Road” stanowi najważniejsze narzędzie służące rozwojowi gospodarczemu i społecznemu państw w tym regionie. Dla państw europejskich szansąjest stworzenie swoistej synergii między inicjatywami chińskimi i europejskimi. Przykładem może być koordynacja tej chińskiej inicjatywy z Europejskim Funduszem na rzecz Inwestycji Strategicznych. W wielu przypadkach inwestycje w Azji Centralnej mogą być realizowane w interesie UE, Chin i Rosji. Przykładem na to może być budowa interoperacyjnego systemu infrastruktury drogowej i kolejowej wzdłuż Jedwabnego Szlaku. System ten mógłby zapewnić możliwość gospodarczej integracji regionalnej, rozwoju regionu i relacji handlowych państw regionu z partnerami zewnętrznymi. Jak wskazuje Krzysztof Kozłowski, brak jest jednak wyraźnego impulsu z obu stron do zacieśnienia relacji (Kozłowski, 2014, s. 54). Chińska polityka wobec partnerów europejskich w Azji Centralnej jest pochodną postrzegania Europy jako konkurenta gospodarczego w skali globalnej nie tylko w tym regionie (Szerzej: Kuczek, 2007). W kontekście możliwości realizacji projektów strategicznych dla regionu wymienić należy obszar zarządzania gospodarką wodną gdzie Unia może przejąć rolę lidera inwestycyjnego.

Równie trudnym co Chiny konkurentem dla unijnych mechanizmów współpracy jest Federacja Rosyjska. Na szczególną uwagę zasługuje kazachsko-rosyjska inicjatywa budowy w nowej formule gospodarczej organizacji regionalnej. Kazachstan jest założycielem unii celnej z Federacją Rosyjską i Białorusią. W maju 2014 r. te trzy państwa oraz Armenia podpisały utworzenie Euroazjatyckiej Unii Gospodarczej. Porozumienie weszło w życie 1 stycznia 2015 roku. W maju do tej grupy dołączył Kirgistan. Podpisane porozumienie może znacząco zagrozić realizacji interesów gospodarczych państw europejskich i odsunąć państwa Azji Centralnej od pogłębiania relacji z partnerami europejskimi. Choć inicjator powstania tej Unii Prezydent Nazarbayew podkreślał chęć otwarcia relacji UE-EUG, powołana do życia 1 stycznia 2015 roku, nowa forma współpracy regionalnej pozostaje dużym wyzwaniem dla dyplomacji unijnej. 
Zarówno partnerzy chińscy, jak i rosyjscy mają szeroki zakres argumentów mogących przekonać państwa Azji Centralnej o wyborze partnerów strategicznych. Co ważne żadne z nich nie uzależnia otrzymania pomocy, napływu inwestycji, od spełnienia warunków w obszarze standardów demokracji czy poszanowania praw człowieka. Można stwierdzić, że Unia jest dla państw regionu w wielu kwestiach niewygodnym partnerem. Odwracając stronę postrzegania wzajemnych relacji, coraz częściej przedstawiciele instytucji unijnych określają państwa regionu jako „trudnych i roszczeniowych klientów" (Olędzki, 2014, s. 43). Oliwia Piskowska posługuje się terminem „partnerzy z przymusu” (Piskowska, 2012, s. 303). Pomimo trudności i innego postrzegania celów współpracy przez partnerów dla Unii Europejskiej w regionie Azji Centralnej najważniejszym obszarem współpracy gospodarczej pozostaje rynek energetyczny. Znaczenie mają tu przede wszystkim zasoby węglowodorów Kazachstanu i Turkmenistanu.

\section{Dialog polityczny dotyczqcy standardów demokracji i przestrzegania praw podstawowych}

W regionie Azji Centralnej występuje bardzo duże zróżnicowanie w poziomie rozwoju kultury politycznej, w tym standardów poszanowania demokracji i praw człowieka. W przyjętych prawnych ramach relacji UE-Azja Centralna strona unijna wielokrotnie deklarowała za ważne przestrzeganie tych standardów 9 . We wszystkich dokumentach dotyczących współpracy Unia wykazuje chęć zaangażowania się we wspieranie i wzmacnianie demokracji, wdrożenie praw obywatelskich, politycznych i praw człowieka, w tym praw socjalnych określonych w pakcie socjalnym ONZ, tworzenie państwa prawa, jak również doskonalenie działań rządowych i administracyjnych państw Azji Centralnej. Nie znajduje to zrozumienia, tym samym aprobaty, ze strony azjatyckich partnerów, którzy ten obszar współpracy uznają za marginalny. Krytycyzm wobec państw europejskich, jak i Federacji Rosyjskiej wynika z doświadczeń historycznych i percepcji różnic kulturowych. Jak zauważa Sebastian Peyrouse, paradoksalnie $\mathrm{w}$ dwóch państwach, gdzie są najbardziej przychylne Rosji elity polityczne, czyli Kazachstanie i Kirgistanie występuje najwyższe poparcie dla współpracy z Unią (Peyrouse, 2014, s. 5).

Przedstawiciele Unii chcą obszar poszanowanie praw człowieka i demokracji uznać za centralny element ich strategii (Axoyonova, 2012). W konsekwencji braku porozumienia $w$ tej materii unijnej stronie na kolejnych kartach swych dokumentów pozostaje „ubolewać nad faktem”, że wynikające z umów o partnerstwie i współpracy zobowiązania prawne w dziedzinie przestrzegania zasad demokracji i praworządności nie zostały właściwie zrealizowane. Wyjątek stanowi sytuacja w Kirgistanie, którego sytuacja różni się znacząco od pozostałych państw. Uznać należy, iż jest to państwo, gdzie standardy demokracji są najbardziej rozwinięte. Jednakże nawet w przypadku

${ }^{9}$ Na obszarze państw Azji Centralnej działania UE w tym obszarze uzupełnione są przez inicjatywy prowadzone przez poszczególne państwa członkowskie. Przykładem może być „platforma na rzecz praworządności” koordynowana przez Niemcy i Francję przy aktywnym wsparciu Finlandii i Łotwy. Jej celem jest organizacja szkoleń, spotkań poświęconych prawu konstytucyjnemu. 
Kirgistanu, kilkakrotnie instytucje unijne, przede wszystkim Parlament Europejski $\mathrm{w}$ formie rezolucji, wypowiadały się w geście solidarności lub zaniepokojenia rozwojem sytuacji na scenie politycznej. Przykładem jest rezolucja ze stycznia 2015 roku dotycząca wprowadzanych w Kirgistanie przepisów tzw. propagandy LGTBI. W pozostałych państwach Azji Centralnej, a zwłaszcza w Uzbekistanie i Turkmenistanie dochodzi do poważnych uchybień poszanowaniu praw człowieka i podstawowych wolności obywatelskich. Zaliczyć do nich można: prześladowanie obrońców praw człowieka, polityków opozycji i dziennikarzy; atakowanie przebywających na wygnaniu przedstawicieli opozycji, w tym zabójstwa i nadużywanie procedur ekstradycji za pośrednictwem Interpolu; represyjne działania w imię ochrony bezpieczeństwa publicznego; ograniczania działalności organizacji społeczeństwa obywatelskiego i partii opozycyjnych, uchwalanie ustaw ograniczających wolność środków przekazu, słowa, zgromadzeń i zrzeszania się; ograniczenia finansowania organizacji społeczeństwa obywatelskiego (ustawy dotyczące ,zagranicznych agentów”) oraz społeczności LGBTI.

\section{Wspótpraca na rzecz bezpieczeństwa}

Wszystkie państwa Azji Centralnej muszą przeciwstawiać się zagrożeniom wynikającym z działalności ruchów islamskich ekstremistów. Grupy te wykorzystują wszelkie spory wewnętrzne, spory graniczne, napięcia na tle etnicznym, aby budować swoją pozycję w regionie. Ekspansja ruchów islamskich ekstremistów jest także bardzo widoczna we wszelkich kwestiach dotyczących regionalnych konfliktów o zasoby. Do innych ważnych aspektów bezpieczeństwa w regionie należy zaliczyć: efekt wojny w Afganistanie, w tym zagrożenia ze strony Państwa Islamskiego, handel narkotykami, handel ludźmi, zagrożenia chemiczne, biologiczne, radiologiczne i jądrowe. $\mathrm{Na}$ rzecz przeciwdziałania tym zagrożeniom Unia poprzez regionalne programy wsparcia uruchomiła środki z Instrumentu na rzecz Stabilności, mającye na celu zapobieganie konfliktom oraz budowanie pokoju, w tym propagowanie pojednania między społecznościami i grupami etnicznymi, a także wytyczenie granic w Azji Centralnej.

Istotną kwestią kształtującą relacje UE z państwami Azji Centralnej jest stabilizacja Afganistanu. Bliskie sąsiedztwo państw Azji Centralnej z Afganistanem stanowi o konieczności tworzenia gwarancji bezpieczeństwa (Gross, 2015). Ważną decyzją było wycofanie z Afganistanu Międzynarodowych Sił Wsparcia Bezpieczeństwa, które zakończono w grudniu $2014 \mathrm{r}$. W kolejnym roku w tym państwie nadal przebywało już tylko około 12000 żołnierzy NATO, w szczególności Amerykanów. Europejskie państwa NATO prowadziły dialog z państwami Azji Centralnej w kontekście ewentualnych konsekwencji operacji wycofywania. Tematyka rozmów skupiona była na zwalczaniu ognisk terroryzmu, niwelowaniu zagrożeń wynikających z działalności ruchów ekstremistycznych, ale także narkotykowej przestępczości zorganizowanej.

Najlepiej, najbardziej efektywnie zainwestowane unijne pieniądze w regionie dotyczą programów współpracy regionalnej wzmacniających współpracę transgraniczną i bezpieczeństwo granic, takich jak Program zarządzania granicami w Azji Środkowej (BOMCA) i Program antynarkotykowy dla Azji Środkowej dotyczący głównie przemytu z Afganistanu (CADAP). Sukces Programu Zarządzania Granicami w Azji Cen- 
tralnej BOMCA oraz programu CADAP nie wpłynął na zniwelowanie źródeł zagrożeń (Boonstra, 2015, s. 3). W latach 2014-2020 uruchomiona została kolejna edycja programu CADAP, gdyż Unia zaalarmowana została rekordowymi uprawami opium i związanym z tym przemytem z Afganistanu przez terytorium Azji Centralnej ${ }^{10}$.

\section{Konkluzje}

Dotychczasową politykę Unii Europejskiej wobec regionu Azji Centralnej cechuje ograniczona liczba inicjatyw budowanych przede wszystkim w oparciu o polityczne deklaracje i strategiczne dokumenty. Stanowi to wyraz tego w jakim stopniu państwom członkowskim UE zależy na zachowaniu politycznego wpływu i ram gospodarczej współpracy z tym regionem. Jakkolwiek unijna dokumentacja wydaje się obszerna, to realne działania unijne jedynie uzupełniają relacje dwustronne pomiędzy poszczególnymi europejskimi państwami a ich azjatyckimi partnerami. Unijne zaangażowanie jest wynikiem presji tylko kilku państw członkowskich, które za parawanem unijnej polityki chcą wzmocnić, bądź legitymizować swoje zwiększone oddziaływanie w regionie. Biorąc pod uwagę geostrategiczne znaczenie Azji Centralnej zaangażowanie Unii w tym regionie jest mniejsze niż można byłoby oczekiwać zwłaszcza w sferze relacji gospodarczych.

Na całościowy charakter unijnej polityki wobec Azji Centralnej składają się: stale ewoluujące ramy prawne określające wzajemne zobowiązania stron współpracy; wzmocnione znacząco po traktacie lizbońskim ramy instytucjonalne; instrumentarium środków finansowych, które mogą być zastosowane na rzecz realizacji założonych celów współpracy. Unia, dysponując tak złożonym mechanizmem, nie jest w stanie w pełni efektywnie prowadzić działań zewnętrznych. Wpływają na to jej wewnętrzne dysfunkcje dotyczące głównie procedur decyzyjnych, ale także narastająca niechęć potencjalnych partnerów do zacieśnienia wzajemnych relacji. Warunkowane jest to konkurencyjną ofertą współpracy ze strony Federacji Rosyjskiej. Strona rosyjska uznaje za godzące $w$ jej interesy przede wszystkim wszelkie unijne projekty energetyczne. Rosyjskie interwencje na Kaukazie, a później na Ukrainie są postrzegane przez państwa Azji Centralnej jednoznacznie jako wyraz pokazania siły. Owocują one poczuciem zagrożenia, co w konsekwencji prowadzi do zacieśnienia relacji z Federacją Rosyjską.

Co ważne, wciąż relatywnie niski stopień instytucjonalizacji stosunków międzynarodowych w tym regionie sprawia, że Unia podejmuje się budowy gospodarczej i politycznej płaszczyzny współpracy ze znaczącym pominięciem istniejącego forum, które grupowałby wszystkie państwa Azji Centralnej i reprezentowało ich interesy na arenie międzynarodowej. Podziały między państwami Azji Centralnej i zróżnicowanie potencjału gospodarczego sprawiają, że Unia w dużej mierze buduje sieć wzajemnych relacji z każdym z państw z osobna dywersyfikując instrumenty zaangażowania i uzależniając ich użycie od aktualnej sytuacji społeczno-gospodarczej.

Bardzo duży wpływ na relacje Unii Europejskiej z państwami Azji Centralnej wywiera inicjatywa utworzenia Eurazjatyckiej Unii Gospodarczej. Od 1 stycznia 2015

${ }^{10}$ Programy BOMCA i CADAP w kolejnym okresie programowania zostaną włączone do Instrumentu na rzecz Stabilności, a nie do Instrumentu Finansowania Współpracy na rzecz Rozwoju. 
roku utworzona została nowa platforma integracji regionalnej. Kazachstan i Kirgistan, liderzy regionalni, opowiedziały się po stronie ścisłej współpracy gospodarczej z Federacją Rosyjska, jednocześnie umiejętnie balansując w kształtowanych więziach z Chinami i państwami Europy Zachodniej. Konsekwencją tego jest parafowanie udoskonalonej umowy o partnerstwie i współpracy z Kazachstanem w grudniu 2015 roku (umowa jest stosowana od 1 maja 2016 roku).

Uznając, że współpraca z tym regionem jest dla Unii Europejskiej ważna, przede wszystkim należy wskazać na płaszczyzny współzależności w obszarze rozwiązywania sporów i konfliktów międzynarodowych w regionie, które mają lub mogą mieć pośredni wpływ na bezpieczeństwo UE oraz jej obywateli, a także w takich obszarach jak handel surowcami energetycznymi.

Zacieśnienie relacji UE z tym regionem jest rozpatrywane poprzez pryzmat pogorszenia relacji z Federacją Rosyjską. Oddziaływanie Unii budzi sprzeciw strony rosyjskiej, która przedstawia atrakcyjne politycznie i gospodarczo propozycje partnerom. Konkurencja gospodarcza i rywalizacja o wpływ na rynek surowców z Azji Centralnej z takimi państwami jak Federacja Rosyjska, Chiny, a także Stany Zjednoczone, wymusza polityczną obecność, której kształt znamionują role, które Unia Europejska chce odgrywać we współczesnym świecie. Reagując w regionie na rzecz gwarancji rozwoju współpracy gospodarczej będącej polem do zabezpieczenia interesów własnych, Unia wpada w pułapkę niemożności realizacji celów dotyczących standardów politycznych. Działania na rzecz gwarancji idei demokracji, państwa prawa, poszanowania praw podstawowych są mało akcentowane. Unijna reakcja na wydarzenia kryzysowe o charakterze politycznym jest w bardzo małym stopniu dostrzegana na arenie międzynarodowej.

W 2012 i 2015 roku dokonano przeglądu Strategii UE wobec Azji Centralnej z roku 2007. Strategia była dokumentem kompleksowym i nakreśliła podstawowe cele współpracy. Jej realizacja pokazuje, że w praktyce strona unijna skupiła się na sektorze energetycznym, nie pomijając kwestii stabilizacji w regionie, wzmocnienia granic, promocji reform gospodarczych. Sfera promocji praw człowieka pozostała jednak w sferze deklaratywnej. W strategii uznano, że relacje będą rozwijać się na płaszczyźnie regionalnej i na płaszczyźnie stosunków bilateralnych. Szczególny nacisk położono na relacje z Kazachstanem i Uzbekistanem. Wadą przyjętego podejścia w strategii jest niesprecyzowanie instrumentów realizacji celów, a także brak konkretnej operacjonalizacji założeń. Przewidywana forma konsultacji międzyrządowych oraz pomocy na rzecz rozwoju nie sprzyja szybkiej realizacji założeń strategii. Za błędne można uznać także niesprecyzowanie indywidualnego podejścia do każdego z państw. Brak zróżnicowania oferty z uwagi na różnorakie problemy poszczególnych państw skutkuje ograniczoną możliwością odpowiedzi na ich potrzeby. Postanowienia strategii są w różnym tempie realizowane. Za sukces można przede wszystkim uznać Program Zarząadzania Granicami w Azji Centralnej BOMCA oraz pogram CADAP dotyczący zwalczania przemytu narkotyków z Afganistanu.

Państwa Azji Centralnej korzystają z instrumentów finansowych współpracy na rzecz rozwoju. Przekazywana kwota, choć znacząco wzrosła, nie jest wystarczająca by efektywnie wpłynąć na zmianę postrzegania Unii jako kluczowego partnera w tym regionie. Porównując do środków zainwestowanych na rzecz rozwoju w innych regio- 
nach świata należy uznać, iż region Azji Centralnej nie został uznany za wymagający szczególnej uwagi, a co się z tym bezpośrednio wiąże zaangażowania finansowego.

Unia dysponuje znaczącym potencjałem gospodarczym i politycznym, by zaznaczać swoją obecność w regionie oraz umiejętnie kształtować relacje z państwami Azji Centralnej. Jednakże o sile Unii decyduje jej spójność i solidarność. By starać się przezwyciężać kryzysy zewnętrzne, w pierwszej kolejności jest konieczne ustabilizowanie sytuacji wewnątrzunijnej. W obliczu kryzysu unijnego przywództwa politycznego dalszy rozwój wzajemnej współpracy będzie pochodną możliwości wypracowania wspólnego stanowiska gwarantującego wzrost pozycji UE na świecie.

\section{Bibliografia}

Axoyonova V. (2012), EU Human Rights and Democratization Assistance to Central Asia: In Need of Further Reform, „EUCAM Policy Brief”, no. 22.

Boonstra J. (2014), Is the EU Downscaling Political Engagement in Central Asia?, „EUCAM Commentary", no. 23.

Boonstra J. (2015), Reviewing the EU's approach to Central Asia, EUCAM, Policy brief, no. 34.

Boonstra J., Tsertsvadze T. (2016), Implemantation and review of the European Union-Central Asia Strategy: Recommendation for EU action, Directorate-General for External Policies.

Cooley A. (2012), The New Great Game in Central Asia. Geopolitics in a Post-Western World, „Foreign Affairs", no. 4.

Council of the European Union (2015), Council conclusions on the EU Strategy for Central Asia, 22 June, http://www.consilium.europa.eu/en/press/press-releases/2015/06/22-fac-centralasia-conclusions/.

European Commission, Regional Strategy Paper for Assistance to Central Asia for the period 2007-2013.

European Parliament (2015), Draft report on implementation and review of the EU-Central Asia Strategy, 7 October 7, http://www.consilium.europa.eu/en/press/press-releases/2015/06/22fac-central-asia-conclusions/.

Europejski Trybunał Obrachunkowy (2013), Pomoc rozwojowa UE dla Azji Środkowej, Sprawozdanie specjalne nr 13.

Gross E. (2015), Recalibrating EU-Central Asia relations European Union, Institute for Security Studies, 16/2015.

HDRO, United Nations Development Programme (2015), Human Development Report. Sustaining Human Progress: Reducing Vulnerabilities and Building Resilience.

Indeo F. (2014), Central Asia beyond 2014: Building Regional Security Architecture, „ISPI Analysis", no. 262.

Kozłowski K. (2015), Polityka Unii Europejskiej wobec Azji Środkowej: Analiza realizacji Strategii na rzecz Nowego partnerstwa z Azja Środkowa, „Kwartalnik Kolegium Ekonomiczno-Społecznego", Studia i Prace, $\mathrm{nr}$ 4(24).

Kuczek K. (2007), Chińsko-europejskie powiqzania w obliczu tranzycji ładu międzynarodowego, „Zeszyty Naukowe Zakładu Europeistyki Wyższej Szkoły Informatyki i Zarządzania w Rzeszowie, $\mathrm{nr}$ 2(4).

Melvin N. (2012), EU Needs a New Value-Based Realism for its Central Asia Strategy, „EUCAM Policy Brief", no. 28.

Olędzki J. A. (2014), Zaangażowanie Unii Europejskiej w rozwój gospodarczy i społeczny Azji Centralnej. Stan i perspektywy, „Studia europejskie”, nr 2, s. 29-55. 
Parlament Europejski (2016), Rezolucja Parlamentu Europejskiego z dnia 13 kwietnia 2016 r. w sprawie realizacji i przegladu strategii UE wobec Azji Środkowej (2015/2220(INI).

Peyrouse S. (2009), Business and Trade Relationship between the EU and Central Asia, EUCAM Working Paper 1.

Peyrouse S. (2014), How does Central Asia view the EU?, EUCAM Working Paper 18.

Piskowska O. (2012), Unia Europejska-Azja Centralna: zarys stosunków, „Społeczeństwo i Polityka", $\mathrm{nr} 4$ (33).

Romanowski M. (2016), The EU in Central Asia: The regional context, European Parliament, Policy Department, Directorate-General for External Policies.

Sprawozdanie w sprawie postęów w realizacji Strategii UE wobec Azji Środkowej, http://www. europarl.europa.eu/sides/getDoc.do?pubRef=-//EP//TEXT+REPORT+A7-2011-0338+0+$\mathrm{DOC}+\mathrm{XML}+\mathrm{V} 0 / / \mathrm{PL}$.

Transparency International Organisation (2015), Corruption Perceptions Index, http://www.transparency.org.

Tsertsvadze T., Boonstra J. (2015), Mapping EU development aid to Central Asia, EUCAM Factsheet 1 .

United Nations, Department of Economic and Social Affairs - Population Division (2015), World Population Prospects, the 2015 Revision, https://esa.un.org/unpd/wpp/Download/Standard/ Population/.

Żuchowska M. P. (2008), Unia Europejska wobec Azji Centralnej-osiagnięcia, perspektywy $i$ wyzwania w rok po ogtoszeniu strategii regionalnej, PISM.

\section{Streszczenie}

Azja Centralna nie jest obszarem priorytetowego zainteresowania ze strony Unii Europejskiej. Choć relacje z państwami regionu nawiązano zaraz po uzyskaniu przez byłe republiki radzieckie niezależności i intensywnie próbowano rozwijać przez następne lata, dzisiejsze efekty współpracy wynikające ze wzajemnych zobowiązań nie są satysfakcjonujące. Celem artykułu jest analiza priorytetów polityki zagranicznej Unii Europejskiej wobec Azji Centralnej po roku 2012. Priorytety zostały przedstawione w dwóch ujęciach: regionalnym i krajowym. Analizie podlegał pełen zakres dokumentów prawnych określających ramy wzajemnych relacji, jak i szersze spektrum obustronnych deklaracji politycznych. Kluczowymi elementami analizy stały się: uwarunkowania kreowania priorytetów politycznych, utworzony mechanizm instytucjonalny niezbędny do kształtowania decyzji politycznej, jak i realizacji założeń współpracy. Artykuł porusza także główne wyzwania w uznanych za kluczowe wymiarach współpracy. Końcowa część analizy prowadzi do wniosków pozwalających na ocenę możliwości realizacji założonych celów polityki unijnej w relacjach z państwami Azji Centralnej.

Słowa kluczowe: Unia Europejska, Wspólna Polityka Zagraniczna i Bezpieczeństwa, UE-Azja Centralna

\section{Determinants shaping foreign policy priorities of the European Union towards Central Asia after 2012}

\section{Summary}

Central Asia is not a priority for the European Union. Relations with the states in this region were established immediately after the former Soviet republics won independence but, despite 
attempts at rapid advancement there, the results of mutual cooperation and mutual commitments have been unsatisfactory. The objective of this paper is to analyze the priorities of the European Union's policy towards Central Asia after 2012. These priorities are viewed from the regional and national perspectives. The analysis studies a comprehensive range of legal documents to establish the framework of mutual relations and the broad range of mutual political declarations. The key elements of this analysis involve examining the determinants that have shaped the political priorities, the institutional mechanisms established for the purpose of political decision-making and the conduct of collaboration. The paper also looks at the main challenges faced in those areas of cooperation that are deemed crucial. The final part of the analysis leads to conclusions that make it possible to assess how feasible it is to implement EU policies in relations with Central Asian states.

Key words: European Union, Common Foreign and Security Policy, EU-Central Asia 